\title{
KOMUNIKASI RINGKAS
}

\section{INVENTARISASI SUMBER DAYA BENIH IKAN BAGI PENGEMBANGAN BUDIDAYA LAUT DI PERAIRAN KUPANG, NUSA TENGGARA TIMUR}

\author{
Badrudin*), Ali Suman*) dan Asep Imam Budiman*)
}

\begin{abstract}
ABSTRAK
Wilayah Kabupaten Kupang, Nusa Tenggara Timur terdiri atas kawasan dengan iklim kering dan lahan kering yang kurang subur sehingga usaha budidaya ikan di laut atau di pantai dapat merupakan salah satu alternatif upaya pemanfaatan sumber daya alam. Salah satu unsur penting untuk budidaya adalah ketersediaan benih secara lokal. Survai ini ditujukan untuk menginventarisasi benih dan induk jenis-jenis ikan yang mempunyai prospek baik untuk di budidayakan.
\end{abstract}

Penangkapan benih telah dilakukan di sekitar Pulau Rote sebanyak 20 kali tawur, Selat Semau 13 kali tawur, Teluk Kupang ke timur laut yang meliputi Oesapa, Sulamu, Barate dan Naikliu sebanyak 15 kali tawur. Alat tangkap yang digunakan adalah pukat pantai' dengan ukuran mata jaring pada kantong 0,5 inchi.

Hasil survai yang besifat inventarisasi ini menunjukkan bahwa benih ikan ekonomis penting yang berpeluang untuk dimanfaatkan bagi usaha budidaya di perairan sekitar Kupang antara lain adalah beronang (Siganus spp.), udang penaeid (Penaeus spp.), kurau (Polynemus spp.), kerapu (Epinephelus spp.), kakap merah (Lutjanus spp.), belanak (Mugil spp.), kuwe (Carangoides spp.), lencam (Lethrinus spp.) dan bandeng (Chanos chanos).

Data yang diperoleh dalam penelitian pendahuluan ini masih bersifat indikatif, di mana kepadatan sediaannya belum dapat diestimasi. Data yang disajikan diharapkan dapat merupakan informasi awal bagi usaha budidaya.

ABSTRACT: The inventory of fish seed resources for mariculture development in Kupang waters area, East Nusa Tenggara. By: Badrudin, Ali Suman and Asep Budiman.

Kabupaten Kupang is wellknown as a dry climate and poor soil area. Mariculture could be an alternative of natural resource utilization. One of the important factors in mariculture is the local availability of fish seed. This survey was intended to obtain information on the availability of fish seed for the possibility of mariculture development in the area.

A beach seine with 0.5 inches cod-end mesh size was used for the inventory. Twenty hauls were carried out in the area of Rote island, 13 hauls in Semau Straits, and 15 hauls in the adjacent waters of Kupang Bay, Barate and Naikliu.

The results showed that the most economically important fish seeds (juveniles) found in the catches were rabbit fish (Siganus spp.), penaeid shrimp (Penaeus spp.), threadfins (Polynemus spp.), groupers (Epinephelus spp.), red snappers (Lutjanus spp.), mullets (Mugil spp.), jack trevallies (Carangoides spp.), emperors (Lethrinus spp.) and milkfish (Chanos chanos).

Data obtained during this resource inventory provide a qualitative indication of the availability of juvenile fish in the areas that are likely utilized for mariculture trials. The abundance of the fish seed in this area was not estimated, so that the data obtained should only be considered as a preliminary result.

KEYWORDS: Fish seed; mariculture; Kupang; East Nusa Tenggara.

*) Peneliti pada Balai Penelitian Perikanan Laut, Jakarta 


\section{PENDAHULUAN}

Sebagian besar wilayah Kabupaten Kupang, Nusa Tenggara Timur terdiri atas kawasan dengan iklim kering dan lahan yang kurang subur sehingga sumber daya laut dan pantai dapat merupakan salah satu alternatif upaya pemanfaatan sumber daya alam. Salah satu sumber daya alam laut dan pantai di perairan sekitar Kupang adalah sumber daya ikan. Sebagaimana halnya dengan perairan kawasan timur Indonesia lainnya yang relatif dalam, perairan di sekitar Kupang juga merupakan perairan yang serupa. Lahan pantai yang landai relatif sempit sehingga peluang pengembangan usaha budidaya tambak skala besar dalam jangka panjang tampaknya tidak akan menguntungkan. Sebaliknya lahan perairan untuk budidaya laut seperti teluk, 'inlet' dan laguna tampaknya cukup banyak, sebagaimana terlihat pada peta pantai baratdaya Timor (Lampiran 1).

Topografi lahan pantai ataupun dasar perairan sekitar Kupang pada umumnya merupakan perairan yang berkarang dengan kemiringan cukup tajam. Perairan yang berkarang ini biasanya merupakan habitat beberapa jenis ikan ekonomis penting seperti kerapu, udang barong, dan ikan karang lainnya. Karena itu wilayah ini diduga cukup potensial bagi pengembangan usaha budidaya laut. Salah satu kendala dalam pengembangan usaha budidaya, baik budidaya laut ataupun budidaya pantai adalah terbatasnya penyediaan benih ikan (Wardoyo dan Rasyid, 1985; Slamet dan Ahmad, 1992). Selanjutnya dijelaskan bahwa sampai saat ini sebagian besar benih ikan untuk budidaya ditangkap dari alam, karena benih ikan yang diproduksi oleh panti benih masih amat terbatas. Sehubungan dengan itu ketergantungan atas ketersediaan benih alam ini tampaknya masih akan terus berlangsung.

Tujuan penelitian pendahuluan ini adalah melakukan inventarisasi sumber daya benih dan induk ikan yang mempunyai prospek baik untuk dibudidayakan di perairan sekitar Kupang. Data yang disajikan masih bersifat indikatif dan belum memberikan gambaran kelimpahan secara kuantitatif, karena hasil tangkapan yang diperoleh relatif amat sedikit. Mengingat bahwa data terdahulu tentang benih dan induk ikan budidaya belum ada, maka hasil yang diperoleh dari kegiatan inventarisasi ini diharapkan dapat merupakan suatu informasi awal dan dapat merupakan unsur penunjang bagi penelitian lebih lanjut dalam rangka pengembangan budidaya ikan laut di wilayah perairan Kupang. Penelitian bersifat 'penjelajahan/eksplorasi' (exploratory survey) di mana sebaran titik-titik pengambilan sampel ikannya tidak disusun dan didasarkan atas suatu rancangan survai atau hamparan ekosistem tertentu.

\section{BAHAN DAN METODE}

Pada bulan Januari-Februari 1996 dilakukan pengambilan sampel benih ikan di sekitar Pulau Rote, Semau serta pantai utara dan selatan Pulau Timor - Kabupaten Kupang pada perairan pantai dengan kedalaman kurang dari $5 \mathrm{~m}$. Alat tangkap yang digunakan adalah pukat pantai (beach seine).

Pengoperasian jaring tersebut sesuai dengan kegiatan survai benih dan induk sebagaimana dilaporkan oleh Badrudin et al. (1996) yaitu: jaring dibawa menuju arah tengah laut dengan bantuan perahu jukung, lalu dibuang ke air secara bertahap sehingga membentuk setengah lingkaran. Dengan bantuan dua buah tali yang masing-masing diikatkan pada kedua ujung jaring, jaring ditarik sampai ke pantai secara perlahan-lahan.

Ukuran mata jaring pada bagian kantong sebesar 0,5 inchi. Ukuran ikan yang tertangkap pada umumnya merupakan 'anak-anak' ikan (yuwana atau juvenile). Identifikasi benih diupayakan serinci mungkin mulai dari kelompok taksonomi yang tinggi, ordo, family, genus sampai spesies. Tiap jenis hasil tangkapan tersebut ditimbang dan dihitung jumlahnya.

Pengambilan sampel benih ikan dilakukan sebanyak 48 kali tawur (haul) dengan perincian 20 kali tawur di sekitar Pulau Rote yang meliputi; Pantai Ndao-Dudale/Baa, Landu Ti, Nusa Manuk, Pouk dan Papela; 13 kali tawur di sekitar Selat Semau yang meliputi Namosain, Teluk Pelikan dan Tablolong; dan 15 kali tawur di sekitar Teluk Kupang yang meliputi Oesapa, Sulamu terus ke timur laut, yaitu Barate dan Naikliu (Lampiran 1). Karena belum ada informasi awal, kegiatan pengambilan sampel ikan yang dilakukan bersifat eksplorasi. 


\section{HASIL DAN PEMBAHASAN}

\section{Hasil}

Hasil pengambilan sampel ikan tersebut dikelompokkan ke dalam: Kelompok I dan II masing-masing sebagai jenis-jenis ikan dan krustasea yang pernah dan atau mempunyai prospek baik untuk dibudidayakan; sedangkan kelompok III dan IV, adalah jenis-jenis ikan dan non-ikan lainnya yang belum mempunyai prospek untuk dibudidayakan (Lampiran 2, 3 dan 4). Benih ikan yang dimaksud adalah yuwana (ikan muda), sedangkan induk adalah ikan-ikan yang sudah matang telur.

\section{Pulau Rote}

\section{(A) Pantai Ndao dan (B) Dudale, Baa.}

Kondisi dasar perairan pantai Ndao adalah berkarang, berpasir serta berlumpur, dengan ekosistem lamun dan hutan mangrove. Pada waktu pasang naik banyak nelayan yang melakukan penangkapan nener di sepanjang pantai. Tiga pengambilan sampel ikan dilakukan di pantai berpasir dan satu tawur lainnya dilakukan di sekitar hutan mangrove dengan dasar perairan lumpur-pasir, lamun dan sedikit berkarang. Perairan pantai Dudale yang berjarak sekitar 1,5 km dari Pantai Ndao, merupakan hamparan pasang surut yang datar dan luas dengan latar belakang pantai hutan mangrove sekitar $1 \mathrm{~km}$ memanjang pantai dengan ketebalan sekitar 0,5 $\mathrm{km}$ dari garis pantai ke arah darat. Perbedaan pasang surut sekitar $1,5 \mathrm{~m}$.

Pengambilan sampel ikan dilakukan sebanyak lima kali tawur. Hasil tangkapan yang terbanyak adalah rajungan (Portunus spp.), udang penaeid dan belanak. Beberapa benih ikan/udang yang cukup banyak adalah udang penaeid ( $P$. semisulcatus, $P$. merguiensis), belanak (Mugil spp.), beronang (Siganus canaliculatus dan Siganus spp.), kakap merah (Lutjanus spp.) dan alu-alu (Sphyraena spp). Hasil tangkapan kumulatif untuk masing-masing lokasi pengambilan sampel di kawasan Pulau Rote (Baa, Dudale, Landu Ti, Pouk dan Papela) disajikan pada Tabel 1. Satu ekor induk beronang dengan bobot 100 gram tertangkap di pantai Ndao. Udang yang tertangkap merupakan jenis udang ekonomis penting yang mempunyai potensi sebagai benih dan induk. Calon induk udang windu ( $P$. semisulcatus) yang tertangkap dalam jumlah banyak dapat dijumpai di pantai Dudale, yaitu sebanyak 183 ekor dengan bobot total $535 \mathrm{~g}$, dan udang putih, P.merguiensis tertangkap sebanyak 193 ekor dengan bobot total sekitar 367 g. Kawasan pengambilan sampel ikan tersebut diduga merupakan daerah asuhan (nursery ground).

\section{(C) Landu Ti}

Sepanjang pantai utara Pulau Landu ditumbuhi oleh mangrove yang jarang dengan dasar perairan yang berkarang dan sedikit lumpur. Pengambilan sampel ikan dilakukan sebanyak tiga kali tawur. Hasil tangkapan dominan adalah cumi-cumi (Sepioteuthis spp.), yaitu sekitar $1,1 \mathrm{~kg}$ dengan jumlah individu 30 ekor. Menurut informasi dari nelayan setempat, sepanjang pantai selatan Pulau Landu yang berkarang, yang dalam kesempatan penelitian ini tidak sempat dikunjungi, merupakan daerah penangkapan lobster. Lokasi penangkapan yang ke.4 dilakukan di sekitar pantai barat Pulau Nusa Manuk yang merupakan perairan jernih dengan dasar berupa pasir dan lamun. Perbedaan pasang tidak begitu tinggi, yaitu sekitar $1 \mathrm{~m}$. Sepanjang pantai berpasir putih dan dipenuhi oleh cangkang moluska yang berserakan. Di pantai ini ditemukan sebuah cangkang Nautilus spp., hewan laut yang dilindungi dan dinyatakan sebagai jenis langka.

Hasil tangkapan pada lokasi ini adalah satu ekor cumi-cumi (Loligo spp.) dengan bobot $100 \mathrm{~g}$, satu ekor beronang (Siganus spp.) dewasa dengan bobot sekitar $50 \mathrm{~g}$ dan sisanya adalah ikan kerong-kerong dan julung-julung.

\section{(D) Pouk - Pantai Baru}

Dusun Pouk terletak di dalam Teluk Korobofo, teluk yang menjorok jauh ke dalam dan banyak sungai-sungai yang bermuara ke dalamnya. Sepanjang pantai banyak dijumpai hutan mangrove. Dasar perairan yang berlumpur yang berasal dari sungai tersebut menyebabkan permukaan air selalu keruh. Di mulut teluk terdapat Pelabuhan Pantai Baru, pelabuhan penyeberangan ferry Rote - Kupang. Perairan ini merupakan daerah penangkapan udang putih yang banyak dilakukan oleh nelayan setempat 
Tabel 1. Komposisi hasil tangkapan kumulatif dengan pukat pantai di perairan Pulau Rote (1996) Table 1. Cumulative catch composition of beach seine in the waters of Rote island (Jan.1996)

\begin{tabular}{|c|c|c|c|c|c|c|}
\hline $\begin{array}{l}\text { Lokasi sampling } \\
\text { Sampling sites } \\
\text { Jumlah tawur } \\
\text { No. of hauls }\end{array}$ & $\begin{array}{l}\mathbf{A} \\
\mathbf{4}\end{array}$ & $\begin{array}{l}\text { B } \\
5\end{array}$ & $\begin{array}{l}C \\
4\end{array}$ & $\begin{array}{l}\text { D } \\
3\end{array}$ & $\begin{array}{l}E \\
4\end{array}$ & $\begin{array}{c}\text { Keterangan } \\
\text { Remarks }\end{array}$ \\
\hline \multicolumn{7}{|l|}{ Group I: } \\
\hline Siganus spp. & $\left.100 / 1^{*}\right)$ & $60 / 32$ & $\left.50 / 1^{*}\right)$ & - & - & \multirow{12}{*}{$\begin{array}{l}\mathrm{A}=\text { Pantai Ndao } \\
\mathrm{B}=\text { Dudale }, \mathrm{Baa} \\
\mathrm{C}=\text { Landu Ti } \\
\mathrm{D}=\text { Pouk, Pantai Baru } \\
\mathrm{E}=\text { Papela } \\
(\ldots / \ldots)=\text { g/total } \\
\text { *) Induk (broodstock) } \\
\text { ikan dewasa, } \\
\text { matang gonad/ } \\
\text { ovarium }\end{array}$} \\
\hline Lutjanidae & $10 / 1$ & & - & - & - & \\
\hline Sphyraena spp. & $5 / 1$ & $40 / 2$ & - & - & - & \\
\hline Mugil spp. & $125 / 14$ & $173 / 22$ & & - & - & \\
\hline Carangidae & - & $37 / 13$ & - & - & $10 / 2$ & \\
\hline Lethrinus sp. & - & - & - & - & $30 / 4$ & \\
\hline Pomadasys hasta & & $5 / 3$ & - & - & - & \\
\hline $\begin{array}{l}\text { Group II: } \\
\text { P. semisulcatus }\end{array}$ & $38 / 10$ & $535 / 183$ & - & $15 / 2$ & $5 / 2$ & \\
\hline P. monodon & - & $10 / 1$ & . & 1 & - & \\
\hline P. merguiensis & - & $367 / 193$ & & $300 / 63$ & - & \\
\hline M. ensis & $10 / 5$ & $-\cdot$ & - & $40 / 23$ & $10 / 5$ & \\
\hline Parapenaeopsis spp. & $1 / 1$ & - & - & • & - & \\
\hline
\end{tabular}

Keterangan (Note): Data diringkas dari Lampiran 2 (Data was summarized from Appendix 2)

dengan menggunakan jaring klitik (bottom gillnet). Selain udang putih, nelayan juga menangkap udang rebon. Pengambilan sampel ikan dilakukan sebanyak tiga kali tawur dengan hasil tangkapan yang dominan adalah udang putih sebanyak 63 ekor dengan bobot sekitar $300 \mathrm{~g}$ dan udang dogol (M.ensis) sebanyak 23 ekor (Tabel 1). Di perairan Pouk ini tidak dijumpai yuwana ikan ekonomis penting kelompok I.

\section{(E) Teluk Papela}

Pengambilan sampel ikan pertama dilakukan di dalam Teluk Papela, yang merupakan perairan dengan dasar berlumpur, pinggir pantai sedikit berkarang dan sepanjang pantai ditumbuhi hutan mangrove yang tipis. Hasil tangkapan didominasi oleh ikan peperek (Leiognathus spp.). Lokasi tawur ke dua dilakukan di pantai selatan pada mulut Teluk Papela yang merupakan pantai berpasir putih dengan dasar sedikit lumpur dan lamun. Hasil tangkapan terbanyak adalah Gerres spp., empat ekor ikan hias dan bintang laut. Dua jenis ikan yang tampaknya mempunyai prospek baik untuk dibudidayakan, yaitu lencam
(Lethrinus lencam, L.miniatus) tertangkap sebanyak empat ekor (30 g) dan ikan kuwe (Carangoides spp.) sebanyak dua ekor (10 g). Hasil tangkapan benih lainnnya adalah 2 ekor udang penaeid ( $P$. semisulcatus) dan lima ekor udang dogol.

\section{Selat Semau}

Selat Semau adalah perairan yang di bagian utara dibatasi oleh Tanjung Namosain dan di selatan oleh Tanjung Oisina. Tiga kali penangkapan dilakukan di barat Teluk Namosain, yang merupakan perairan pasang surut dengan dasar berupa pasir berlumpur dan sedikit lamun. Hasil tangkapan cukup beragam. Induk ikan beronang (Siganus spp.) sebanyak 5 ekor dengan bobot sekitar $300 \mathrm{~g}$ dan rajungan (Portunus spp.) merupakan jenis yang paling banyak tertangkap. Di perairan ini tertangkap pula yuana ikan kurau (Polynemus spp.) kakap merah (Lutjanus spp.), lencam (Lethrinus spp.) dan udang windu ( $P$. semisulcatus). Pada dua kali penangkapan di timur Teluk Namosain, pada perairan sedikit 
berbatu dan dekat muara sungai kecil dengan air yang lebih keruh hanya diperoleh jenis ikan serinding (Apogon spp.) dan rajungan (Portunus spp.). Di Teluk Pelikan pada perairan yang lebih jernih dekat dengan ekositem mangrove yang agak tebal dilakukan dua kali tawur. Dasar perairan sedikit berlumpur dan berkarang. Di sekitarnya terdapat rumah-rumah penduduk Desa Bakonusan.

Dari hasil pengambilan sampel ikan tidak diperoleh adanya benih ikan ekonomis penting. Sebagian besar jenis ikan yang tertangkap kecuali alu-alu (Sphyraena spp.) adalah jenis ikan berukur kecil seperti peperek, kepala batu (Atherina spp.) dan kuniran yang harganya relatif rendah (Lampiran 3). Teluk Pelikan yang diperkirakan merupakan areal yang baik untuk budidaya ikan, dewasa ini sudah merupakan kawasan budidaya mutiara skala industri, sehingga peluang untuk kegiatan budidaya laut lainnya tampaknya sudah tertutup.

Di bagian utara pantai Tablolong pada perairan dengan dasar berupa pasir, lamun dan ganggang hijau (Fucus spp.) yang sangat lebat dilakukan dua kali tawur. Daerah lepas pantai Tablolong dewasa ini sedang dipromosikan sebagai kawasan rekreasi pemancingan. Hasil tangkapan dominan adalah cumi-cumi (Sepioteuthis spp.) sebanyak 14 ekor dengan bobot sekitar 900 g, dan kapas-kapas (Gerres spp.) sebanyak 13 ekor. Hasil tangkapan pada dua kali tawur lainnya di selatan Tablolong didominasi oleh induk beronang ( $S$. canaliculatus) sebanyak 5 ekor dengan bobot sekitar $740 \mathrm{~g}$, satu ekor benih ikan kakap merah (Lutjanus spp.) dan satu ekor benih ikan lencam (Lethrinus spp.).

Di perairan Selat Semau ini terdapat kegiatan penampungan ikan kerapu hidup dalam dua unit karamba jaring apung dengan lokasi yang berpindah-pindah tergantung kepada arah angin. Pada musim barat, keramba ditambatkan lebih ke dekat Pulau Semau yang agak terlindung dan pada musim timur dipindahkan ke bagian selat yang lebih dekat ke pantai antara Tenau, Bolok dan Tablolong.

\section{Teluk Kupang, Barate dan Naikliu}

Pada tiga dari empat kali tawur di Oesapa, barat daya Teluk Kupang, selalu dijumpai benih ikan kurau (Polynemus spp.) yang tertangkap se- banyak 11 ekor dengan bobot $90 \mathrm{~g}$. Benih ikan lainnya adalah satu ekor belanak (Mugil spp.), tujuh ekor ( $43 \mathrm{~g}$ ) gerot-gerot (Pomadasys hasta) dan tujuh ekor $(20 \mathrm{~g})$ ikan kuwe (Carangoides spp.). Perairan pantai Sulamu, timur laut Teluk Kupang, merupakan pantai berpasir putih dengan dasar perairan lumpur berpasir, padang lamun dan rumput laut. Hasil tangkapan di bagian selatan didominasi oleh ikan muda jenis Ilisha spp. (447 ekor) dan rajungan jenis kecil, sedangkan pada tiga kali tawur di bagian utara ditemukan satu ekor benih ikan beronang ( $S$. canaliculatus), 15 ekor udang windu $(P$. semisulcatus), empat ekor belanak (Mugil spp.), satu ekor kerapu sunu (Cephalopolis spp.) dan tiga ekor bandeng (Chanos chanos).

Di balik Tanjung Barate, dekat muara sungai kecil yang terbuka ke Laut Sawu telah dilakukan tiga kali tawur. Gelombang laut cukup tinggi. Topografi dasar perairan membentuk kemiringan yang cukup terjal, dengan pantai yang berpasir putih tanpa mangrove. Jenis ikan yang dominan tertangkap adalah peperek. Di perairan ini tertangkap satu ekor yuwana ikan kurau (Eulethronema spp.) dan satu ekor yuwana ikan tenggiri (Scomberomorus commersoni). Dalam perjalanan ke Naikliu, di lepas pantai Barate telah tertangkap dengan pancing tonda seekor induk ikan tenggiri (S. commersoni) matang telur dengan bobot sekitar $15 \mathrm{~kg}$.

Di barat Teluk Naikliu, dekat muara sungai dengan dasar perairan yang berpasir dan miring terjal telah dilakukan dua kali tawur. Sebagaimana halnya dengan perairan Teluk Barate, gelombang laut di Naikliu ini cukup tinggi. Ikan yang dominan tertangkap adalah peperek (Leiognathidae) dan karangid (Carangidae). Yuwana ikan ekonomis penting adalah kurau, Polynemus spp. yang tertangkap sebanyak tiga ekor. Pada satu lokasi tawur di sebelah timur Teluk Naikliu diperoleh jenis ikan kuwe, Carangoides spp. yang tertangkap sebanyak 12 ekor dengan bobot $180 \mathrm{~g}$. Pada jarak sekitar satu mil dari pantai terlihat nelayan yang meng. operasikan jaring lingkar dengan hasil tangkapan yang seragam, yaitu tembang, Sardinella albella.

Kegiatan penangkapan nener oleh nelayan selama periode survai yang merupakan musim hujan, dijumpai di pantai Ndao-Baa dan LasianaTeluk Kupang, sedangkan di kawasan pantai antara Barate, Soleu dan Naikliu menurut 
informasi dari nelayan hanya diusahakan pada musim kemarau. Kegiatan penangkapan udang penaeid dengan trammel net di Teluk Kupang, meski tidak dimaksudkan untuk semata-mata menangkap induk, dilakukan oleh nelayan Oeteta.

\section{Pembahasan}

Pengambilan sampel benih ikan dengan menggunakan pukat pantai yang telah dilakukan meliputi perairan dengan ekosistem estuaria, mangrove, padang lamun dan perairan yang berkarang. Di perairan sekitar Kupang yang menjadi daerah penelitian, keempat ekosistem tersebut dapat ditemukan dan sebarannya telah dilaporkan oleh P3O-LIPI (1995). Ekosistem estuaria, mangrove dan lamun merupakan daerah asuhan untuk berbagai jenis ikan (Lovelock, 1993), sedangkan perairan yang berkarang biasanya merupakan habitat beberapa jenis ikan lutjanid, serranid (Linting et al., 1991; Badrudin et al., 1991) atau udang barong (Bathia, 1974), dan berbagai jenis ikan karang lainnya (Salm and Clark, 1985).

Data hasil tangkapan untuk tiap lokasi adalah data kumulatif karena hasil tangkapan per tawur relatif amat sedikit, yang bersifat indikatif dan belum menggambarkan indeks kelimpahan stok. Hal ini disebabkan karena pembakuan luas daerah sapuan (swept area) sangat sulit dilakukan. Sedikitnya hasil tangkapan mungkin dipengaruhi oleh kelimpahan benih tersebut yang sangat erat kaitannya dengan musim. Sebagaimana dilaporkan oleh Sugama and Eda (1985) bahwa melimpahnya yuwana ikan di suatu perairan bersifat musiman. Keadaan yang sama juga terjadi di perairan sekitar Kupang terutama untuk jenis ikan beronang (Siganus spp.), dan nener bandeng (Chanos chanos). Menurut nelayan Namosain, yuwana ikan beronang pada bulan-bulan tertentu sering tertangkap dalam jumlah yang banyak pada perairan pantai dengan ekosistem lamun. Demikian juga dengan nener, di mana musim penangkapan yang melimpah biasanya terjadi pada sekitar musim kemarau antara MeiOktober, sebagaimana dilaporkan oleh Wardoyo dan Rasyid (1985). Pada musim ini biasanya kecerahan air laut sangat jernih dengan kadar garam yang cukup tinggi. Informasi dari pedagang pengumpul nener di Kupang menguatkan dugaan bahwa kegiatan penangkapan nener tersebut berlangsung antara bulan Mei-Oktober.

Pengembangan agribisnis budidaya ikan laut dalam karamba jaring apung memerlukan dukungan informasi tentang kondisi oseanografis yang optimum berupa kisaran parameter biofisik perairan seperti kecepatan arus, pola pasang surut, topografi dasar dan faktor lainnya seperti ketersediaan benih dan pakan secara lokal. Sampai saat ini panti benih tampaknya belum mampu berproduksi secara ekonomis sehingga benih yang ditangkap dari alam merupakan satusatunya alternatif. Adanya indikasi benih ikan budidaya di sekitar Rote, Selat Semau dan Kupang ini merupakan informasi awal bagi kemungkinan pengembangan usaha budidaya laut pada tahap uji-coba usaha skala kecil. Informasi yang diperoleh baru mencakup waktu dua bulan (Januari dan Februari), sehingga adanya informasi pada bulan lainnya akan merupakan informasi tambahan bagi terlaksananya usaha budidaya yang lebih baik dan menguntungkan.

\section{KESIMPULAN DAN SARAN}

\section{Kesimpulan}

Dari hasil penelitian pendahuluan yang masih bersifat kualitatif dan indikatif ini telah diperoleh benih dan induk beberapa jenis-jenis ikan, krustasea dan moluska ekonomis penting.

Benih ikan ekonomis penting yang dapat dimanfaatkan bagi usaha budidaya laut di perairan sekitar Kupang antara lain adalah beronang (Siganus spp.), kurau (Polynemus spp.), kerapu (Epinephelus spp.), kakap merah (Lutjanus spp.), belanak (Mugil spp.), ikan kuwe (Carangoides spp.), lencam (Lethrinus spp.) dan bandeng (Chanos chanos).

Benih kelompok krustasea sebagian besar adalah udang penaeid, yang terdiri atas udang putih (Penaeus merguiensis), udang windu (Penaeus semisulcatus dan P.monodon) dan udang dogol (Metapenaeus ensis) dan dari kelompok moluska adalah cumi-cumi (Loligo spp. dan Sepioteuthis spp.). 


\section{Saran}

Bagi pengembangan usaha budidaya ikan laut secara komersial, informasi tentang ketersediaan benih dan induk ikan menurut tempat dan musim merupakan unsur penting. Hasil penelitian pendahuluan ini diharapkan dapat merupakan langkah awal bagi penelitian lebih lanjut baik dalam rangka eksplorasi/inventarisasi sumber daya alam maupun dalam menunjang kegiatan pengembangan budidaya ikan laut. Dengan demikian, informasi yang diperoleh dapat meliputi kurun waktu yang lebih panjang, sehingga data sebaran 'spasial' dan 'temporal' induk dan benih ikan akan lebih beragam, akurat, dan dapat diprediksi paling tidak untuk perairan sekitar Teluk Kupang.

\section{DAFTAR PUSTAKA}

Badrudin, M., A. Suman, A. Purnomo, Dharmadi, K. Wagiyo, R. Basuki dan I.N. Radiarta. 1996. Laporan survai sumberdaya dan sosial ekonomi perikanan di wilayah 'MCMA' Teluk Kupang, Nusa Tenggara Timur. Pusat Penelitian dan Pengembangan Perikanan - Marine Resource Evaluation and Planning (MREP) - Badan Kordinasi Survai dan Pemetaan Nasional. Jakarta. 113 p.

Badrudin, M.E. Amin, T. Akhmad dan W. Ismail. 1991. Potensi pengembangan budidaya karamba jaring apung laut di perairan Sendang Biru, Karimun Jawa dan Teluk Banten. Bull. Pen.Perikanan No.3. Pusat Penelitian dan Pengembangan Perikanan. Jakarta : 1-18.
Bathia, U. 1974. Distribution of spiny lobsters along the west coast of Thailand with observation on their fishing grounds. Research Bulletin No.5. Phuket Marine Biological Center. Phuket.Thailand. 20 p.

Linting, M., Mahiswara, R. Basuki, P.T. Imanto dan Badrudin. 1991. Potensi benih ikan budidaya di perairan Teluk Trima, Bali. Bull.Pen.Perikanan. No.3. Pusat Penelitian dan Pengembangan Perikanan. Jakarta : 179-191

Lovelock, C. 1993. Field guide to the mangroves of Quennsland. Australian Institute of Marine Science. 72p.

P3O-LIPI. 1995. Laporan survey di MCMA Teluk Kupang. Pusat Penelitian dan Pengembangan Oseanologi/LIPI. Jakarta. 291 p.

Salm, R.V. and J.R. Clark. 1984. Marine and coastal protected areas: A guideline for planners and managers. IUCNNR. Glend. Switzerland. 302 p.

Slamet, B. dan T. Ahmad. 1992. Kelimpahan benih ikan kerapu lumpur, Epinephelus tauvina, di perairan Teluk Banten. Jur.Pen.Budidaya Pantai. Vol. 8. No.2. Balai Penelitian Perikanan Budidaya Pantai. Maros : 93-100.

Sugama, K. and H. Eda. 1985. Survei benih ikan kerapu, Epinephelus spp. di perairan Teluk Banten. Scientific Report of Mariculture Research and Development Project (ATA-192) in Indonesia. JICASub Balitdita Serang : 179-191 pp.

Wardoyo, S.E. dan F.Rasyid. 1985. Sumber benih baru di Indonesia Timur untuk menanggulangi masalah perkembangan tambak. Jur.Pen.Budidaya Pantai. Thn.1, No.1. Balai Penelitian Budidaya Pantai. Maros : 1-8. 


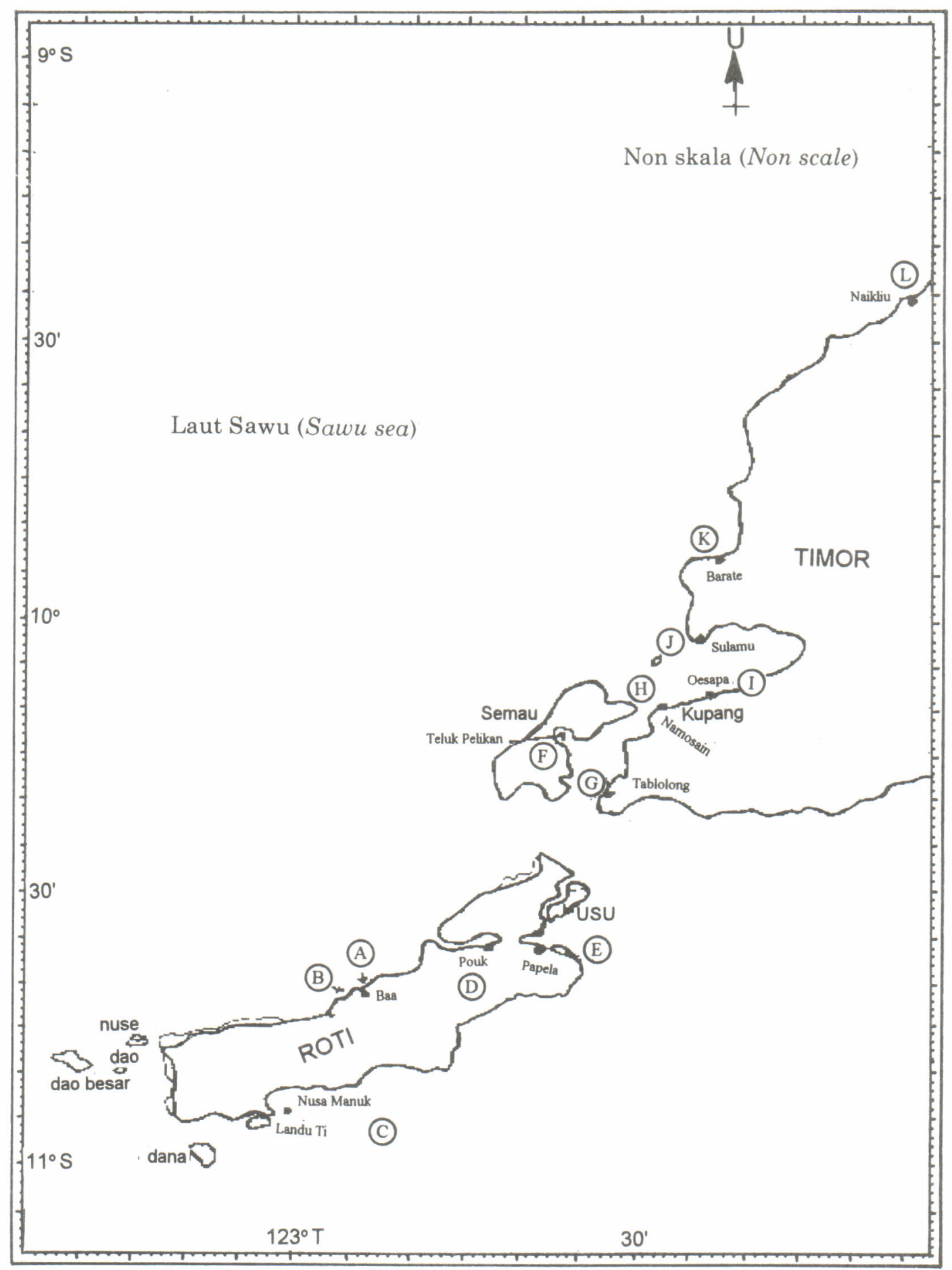

Lampiran 1. Lokasi pengambilan sampel benih ikan di perairan Kupang, Nusa Tenggara Timur. Appendix 1. Sampling sites of fish seed in Kupang waters, East Nusa Tenggara. 
Lampiran 2. Komposisi hasil tangkapan kumulatif dengan pukat pantai di perairan Pulau Rote (Januari 1996)

Appendix 2. Cumulative catch composition of beach seine in the waters of Rote Island (January 1996)

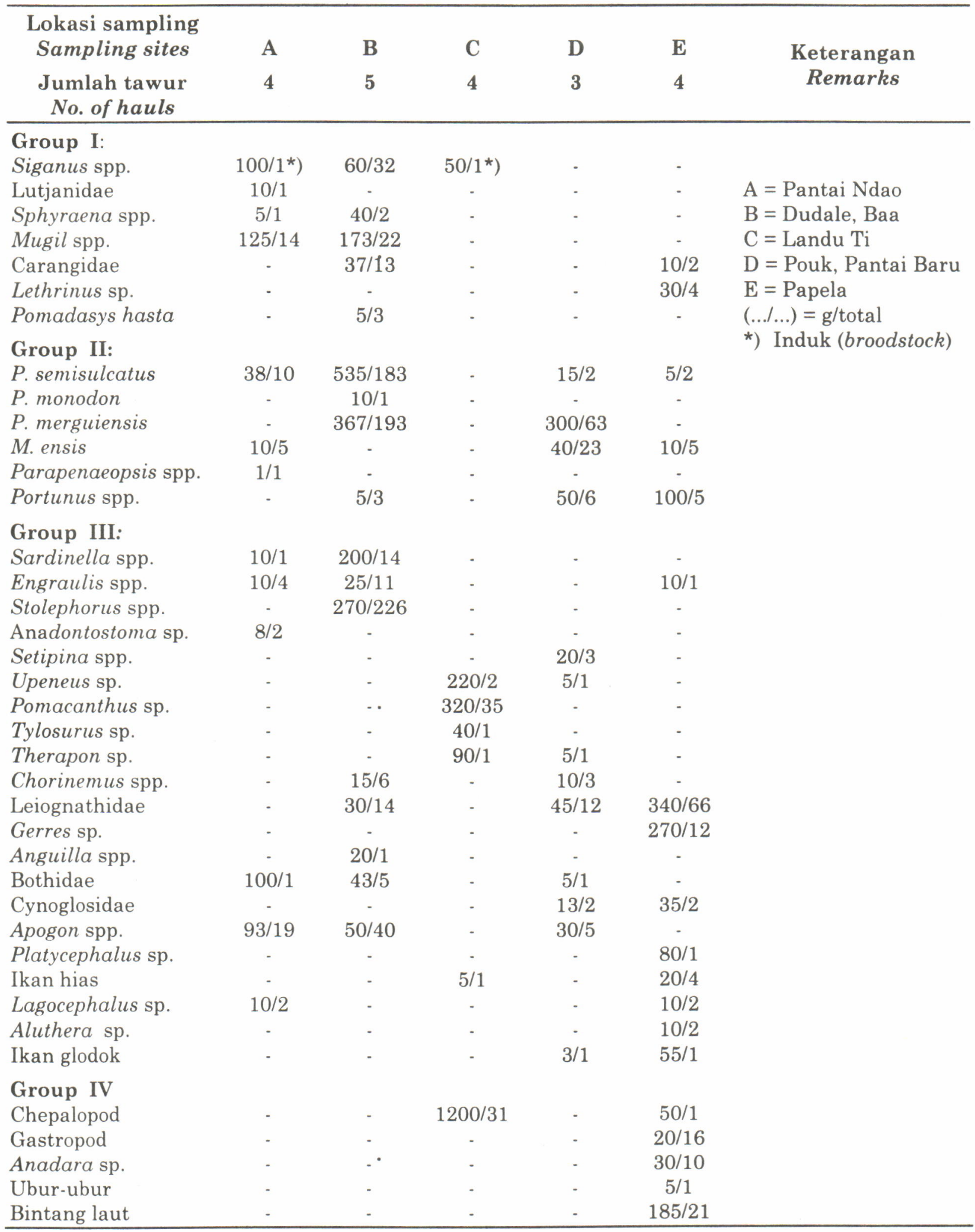


Lampiran 3. Komposisi hasil tangkapan kumulatif dengan pukat pantai di perairan Selat Semau, Kupang NTT (February 1996).

Appendix 3. Cumulative catch composition of beach seine in the waters of Semau Straits, Kupang, East Nusa Tenggara (February 1996).

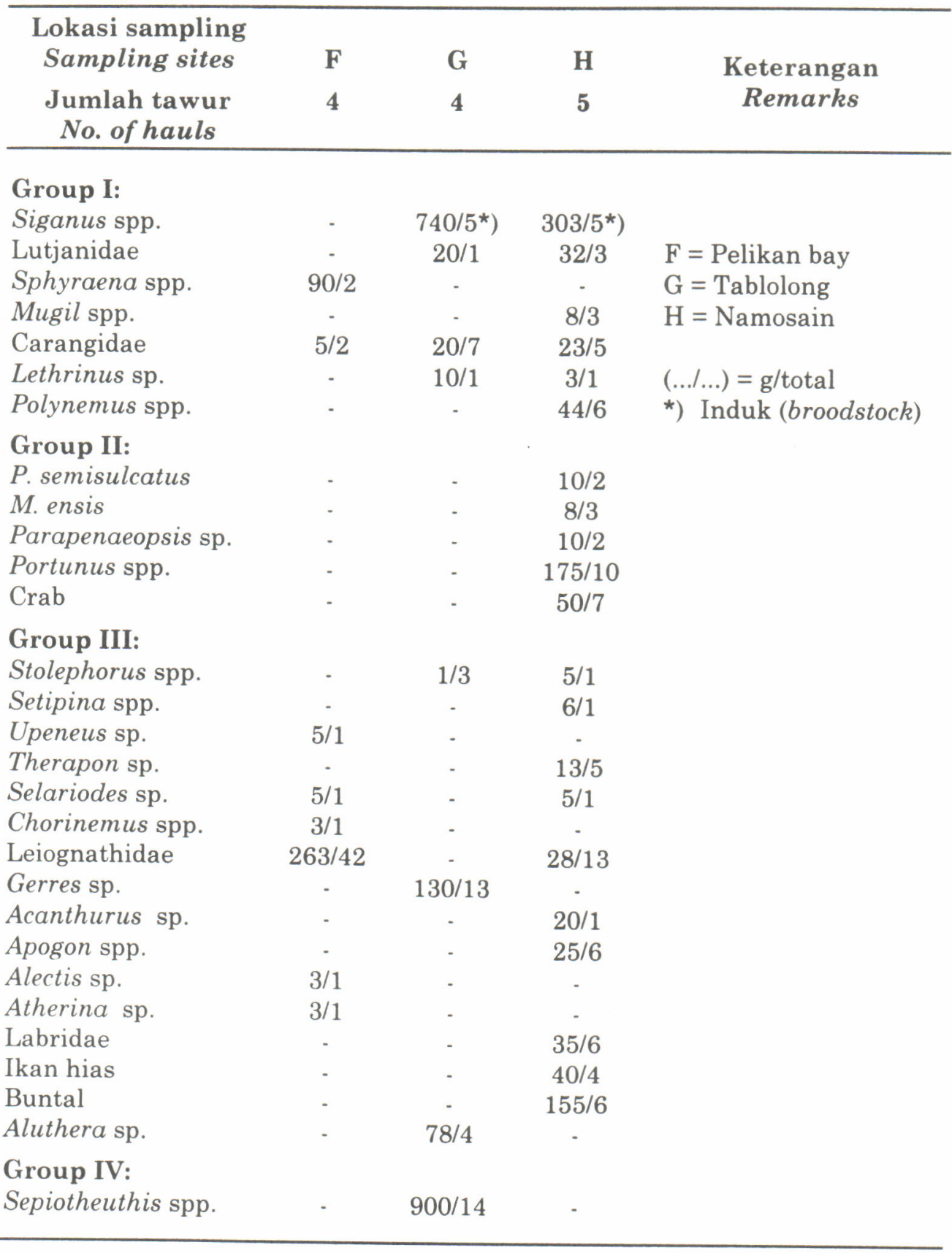


Lampiran 4. Komposisi hasil tangkapan kumulatif dengan pukat pantai di perairan Teluk Kupang dan Teluk Naikliu, NTT (February 1996)

Appendix 4. Cumulative catch composition of beach seine in the waters of Kupang Bay, Barate Bay and Naikliu Bay, East Nusa Tenggara (February 1996).

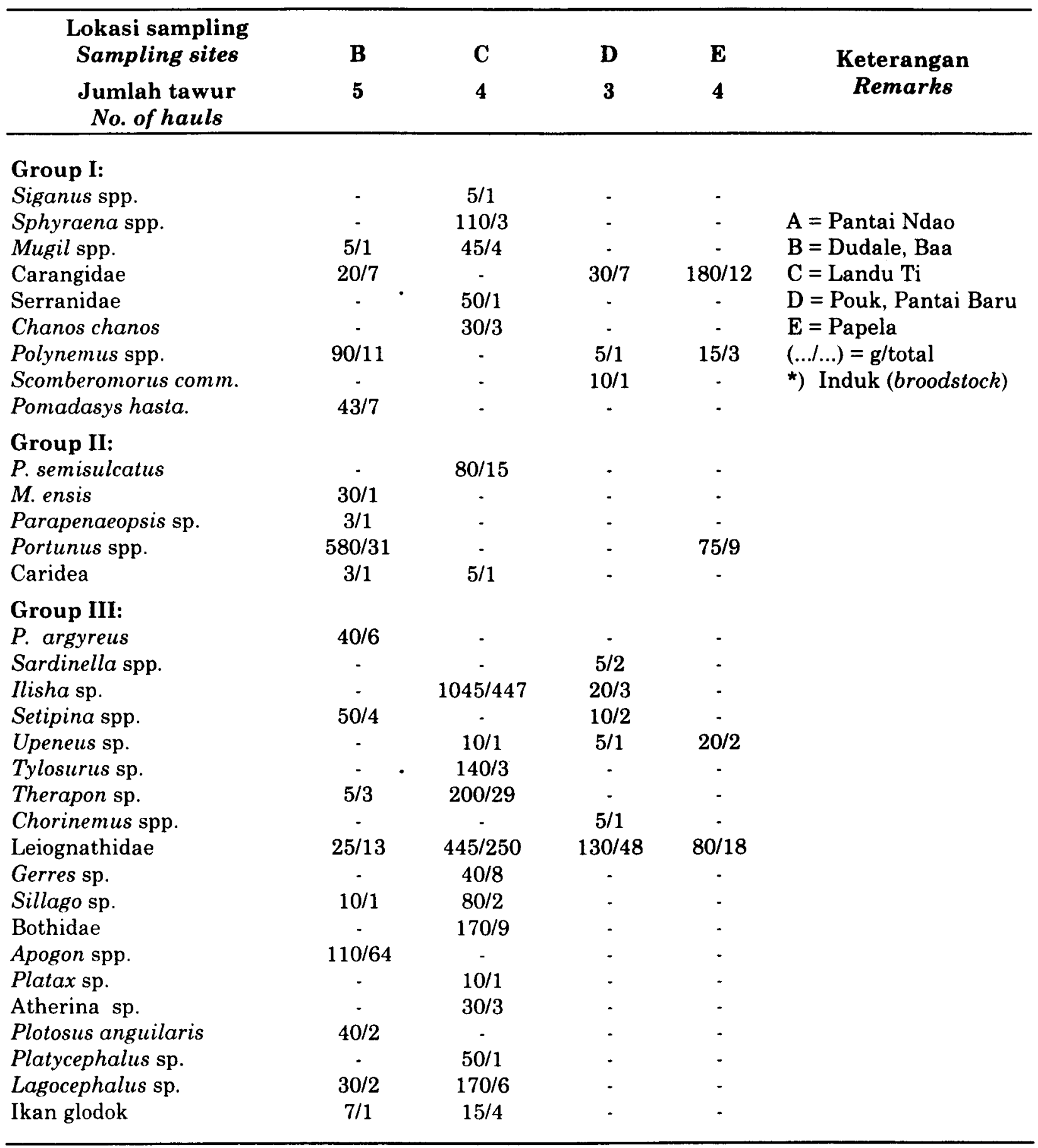

